\title{
Identifikasi permasalahan pengambilan keputusan karir remaja
}

\author{
Ruseno Arjanggi \\ Fakultas Psikologi Universitas Islam Sultan Agung \\ Email: ruseno@unissula.ac.id
}

\begin{abstract}
ABSTRAK
Tujuan penelitian ini adalah untuk mengeksplorasi profile kesulitan pengambilan keputusan karir pada remaja. Pengambilan keputusan karir merupakan permasalahan yang krusial dihadapi oleh remaja. Keterlambatan dalam proses bimbingan maupun konseling karir akan berdampak pada kebingungan dalam pengambilan keputusan karir remaja. Bahkan memungkinkan remaja akan merasa bahwa jurusan yang diambil dalam pendidikan lanjutan dirasa tidak tepat.

Partisipan penelitian ini adalam siswa-siswi sekolah menengah atas dan kejuruan di kota semarang dengan sejumlah 566 siswa. Instrument ukur yang digunakan adalah skala kesulitan pengambilan keputusan karir. Data yang diperoleh ditabulasi dan dianalisis untuk mendapatkan deskripsi statistik profile.

Berdasarkan hasil analisis data diketahui bahwa tingkat kesulitan pengambilan keputusan karir remaja masih tinggi. Hasil uji statistik terhadap perbedaan kesulitan pengambilan keputusan karir berdasarkan gender diketahui bahwa remaja perempuan lebih sulit dalam mengambil keputusan karir. Hasil penelitian perlu dikaji lebih mendalam mengenai perbedaan tersebut.
\end{abstract}

Kata kunci : pengambilan keputusan, karir, remaja

\section{Pengantar}

engambilan keputusan Karir
merupakan
penting yang dapat digunakan

selama satu rentang kehidupan seseorang (Zunker, 2006). Pengambilan keputusan karir merupakan ketrampilan yang dapat dipelajari. Tahapan dalam proses pengambilan keputusan karir dilalui dengan mengindentifikasikan dan ketrampilan pengolahan informasi (Zunker, 2006). Keputusan karir merupakan proses yang kompleks, akibatnya konselor karir dihadapkan dengan berbagai kesulitan yang dialami individu ketika membuat keputusan karir (Germeijs \& Verschueren, 2006).

Chance events seperti job fair diketahui mampu mempengaruhi keputusan karir dari 69,1\% sampel dan locus of control secara moderat berhubungan dengan chance events (Bright, Pryor, \& Harpham, 2005). Efikasi diri pengambilan keputusan karir sebagai variabel intervening dukungan orang tua dan dukungan guru terhadap optimisme karir pada mahasiswa di pilipina (Garcia, Restubog, Bordia, Bordia, \& Roxas, 2015).

Remaja merupakan usia yang labil sehingga ada variasi yang cukup besar 
antara di tingkat awal mereka karir dan di tingkat perubahan keputusan dalam penentuan karir berikutnya (Germeijs \& Verschueren, 2006). Lebih lanjut dijelaskan Pertumbuhan dalam orientasi yang berkaitan dengan pertumbuhan lingkungan dan eksplorasi diri, dan pertumbuhan eksplorasi lingkungan akan berkaitan dengan kemajuan dalam komitmen dan status putusan karir (Germeijs \& Verschueren, 2006). Pentingnya menentukan pilihan diawal sebelum masuk perguruan tinggi memiliki hubungan dengan prestasi akademik selama tahun pertama dalam pendidikan tinggi (Germeijs \& Verschueren, 2007).

Seseorang yang memiliki kepribadian kebutuhan untuk profesional memiliki pengaruh dalam alternatif pemilihan karir mereka atau pengembangan karir (Guranda, 2014). Mengidentifikasi minat dalam kaitannya dengan tipe kepribadian, dapat mencapai implementasi sistem nilai-nilai profesional atau perencanaan ulang karier dicapai pada orang dewasa (Guranda, 2014). Hal ini tentu berbeda dengan pola pengambilan keputusan karir pada remaja yang masih cenderung labil. Individu dewasa meningkatkan kesesuaian antara persyaratan profesi dan kepentingan profesional dengan cara mendukung dan melakukan identifikasi analisis alternatif selama proses pengambilan keputusan.

Pada latar belakang budaya yang berbeda ditemukan bahwa semakin adaptif profile pengambilan keputusan karir seseorang, semakin kecil kesulitan dalam mengambil keputusan (Willner, Gati, \& Guan, 2015). Perbedaan budaya tidak selalu memiliki makna dalam mempengaruhi pemilihan karir remaja, karena remaja memiliki karakteristik yang hampir sama pada beberapa budaya (Willner et al., 2015). Berdasarkan penelitian sebelumnya maka penelitian ini tertarik untuk mengindentifikasi profile kesulitan pengambilan keputusan karir pada remaja. Menurut sepengetahuan peneliti belum ada penelitian sejenis dilakukan di kota semarang.

\subsection{Pengambilan Keputusan Karir}

Pengambilan keputusan karir dikembangkan berdasarkan teori pengambilan keputusan, dan membuat keputusan karir merupakan proses yang kompleks (Gati, Krausz, \& Osipow, 1996). Berdasarkan teori normatif pengambilan keputusan, pengambilan keputusan terbaik adalah yang membantu individu untuk mencapai tujuan pembuatan keutusan tersebut (Gati et al., 1996). Pengambilan keputusan karir adalah suatu proses penentuan yang diawali pemilihan alternatif melalui perbandingan dan evaluasi alternatif yang tersedia.

Siswa mengembangkan suatu pemahaman proses berpikir kritis yang sesuai untuk diaplikasikan dalam ketrampilan pengambilan keputusan karir (Patton \& McMahon, 2001). Ada berbagai faktor yang mempengaruhi pengambilan 
keputusan karir remaja yaitu kondisi kekinian yang meliputi : teman sebaya, lokasi geografis, institusi pendidikan, dan kondisi politik (Patton \& McMahon, 2001). Kondisi masa lalu yang mempengaruhi proses pemilihan karir remaja diantaranya : pasar kerja, tempat kerja, status sosial ekonomi, dan kelompok komunitas (Patton \& McMahon, 2001). Sedangkan kondisi yang akan datang yang mempengaruhi pemilihan karir remaja yaitu : keluarga, trend sejarah, media, dan globalisasi (Patton \& McMahon, 2001).

Beberapa penelitian sebelumnya dengan tema dan konstrak teori yang sama menghubungkan kesulitan pengambilan keputusan karir remaja dipengaruhi pengharapan orang tua dan orientasi nilai budaya (Leung, Hou, Gati, \& Li, 2011). Perbedaan status sosial dengan variabel moderator identitas pekerjaan berpengaruh dalam pengambilan keputusan karir (Li, Hou, \& Jia, 2015). Perbedaan sumber dukungan sosial berpengaruh dalam pengambilan keputusan karir (Vertsberger \& Gati, 2015). Penelitian ini merupakan studi awal, jadi baru pada tahap pengembangan alat ukur dan studi profile kesulitan pengambilan keputusan karir remaja.

\subsection{Remaja dan Karir}

Tugas utama dari tugas perkembangan remaja adalah mencapai kesuksesan di sekolah pada level akademis dan social, karena merupakan jaminan dari adanya penyesuaian sekolah dan prestasi akademis (Bernier, Soucy, \& Larose, 2004). Tahap remaja menengah ditandai dengan perilaku seksual aktif, membuat keputusan moral (tentang baik-buruk), keseimbangan antara otonomi dan keterbukaan, dan pengembangan hubungan baru dengan teman sebaya (Micucci, 2009). Remaja menengah secara usia kalender dimulai umur 14 hingga 16 tahun (Micucci, 2009) dan usia tersebut merupakan usia Sekolah Menengah Atas. Pengembangan penelitian ini akan memberikan dampak terhadap pengurangan kesulitan pengambilan keputusan karir remaja melalui intervensi yang tepat yang akan direkomendasikan berdasarkan hasil penelitian ini. Permasalahan nisbah masa studi di perguruan tinggi atau profesi yang tidak sesuai dengan latar belakang ketrampilan yang dipelajari dan tingkat pendidikan disebabkan kesulitan dalam penagmbilan keputusan karir yang tidak diantisipasi sebelumnya oleh remaja. Tujuan penelitian ini adalah untuk memberikan profile tentang permasalahan kesulitan pengambilan keputusan karir pada remaja di kota semarang.

\section{Metode Penelitian}

\subsection{Partisipan Penelitian}

Partisipan penelitian ini adalah siswa SMA kelas X di kota semarang. Partisipan penelitian melibatkan SMA dan SMK. di kota semarang Pengambilan sample penelitian ini menggunakan random klaster untuk menentukan sekolah dan kelas yang akan 
menjadi partisipan dalam penelitian. Jumlah keseluruhan partisipan penelitian ini adalah 566 siswa kelas X SMA dan SMK di kota Semarang yang terdiri dari 199 siswa laki- laki dan 366 siswa perempuan, 493 siswa SMA dan 73 siswa SMK. Sebaran data demografi responden dijabarkan dalam tabel 1 dan tabel 2

Tabel 1. Distribusi sampel penelitian berdasarkan gender

\begin{tabular}{lrr}
\hline Jenis kelamin & Frequency & Percent \\
\hline Laki-laki & 199 & 35.2 \\
Perempuan & 366 & 64.7 \\
\hline Total & 566 & 100.0 \\
\hline
\end{tabular}

Tabel 2. Distribusi Sampel Penelitian Berdasarkan Jenis Sekolah

\begin{tabular}{lrr}
\hline Jenis sekolah & Frequency & Percent \\
\hline Umum & 493 & 87.1 \\
Kejuruan & 73 & 12.9 \\
\hline Total & 566 & 100.0 \\
\hline
\end{tabular}

\subsection{Instrumentasi}

Skala yang digunakan dalam penelitian ini merupakan adaptasi Career Decision Difficulties Questionnaire (Gati et al., 1996). Skala ini dibagi dalam dua bagian, yaitu: sebelum hingga awal proses pengambilan keputusan karir, kesulitan selama proses pengambilan keputusan (Gati, Gadassi, \& Mashiah-Cohen, 2012; Gati, Gadassi, \& Shemesh, 2006; Gati et al., 1996; Gati, Landman, Davidovitch, Asulin-Peretz, \& Gadassi, 2010; Gati, Ryzhik, \& Vertsberger, 2013). Skala aslinya menggunakan poin pilihan model likert dengan 9 range pilihan respon dari skor 1 sangat tidak menggambarkan diri saya hingga skor 9 sangat menggambarkan diri saya (Gati et al., 2013). Sedangkan pada penelitian ini hanya menggunakan lima pilihan respon yang sudah populer di Indonesia.

\section{Hasil dan Pembahasan}

Berdasarkan uji daya beda aitem terhadap skala CDDQ diketahui bahwa 15 aitem memiliki daya beda rendah dibawah 0,3 yaitu aitem no $1,2,3,5,6,8,9,10,34,35$, 39, 40, 41, 42, dan 43. Indeks reliabilitas aitem skala CDDQ sebesar $\alpha=0,849$, yang berarti memuaskan. Namun demikian banyaknya aitem yang gugur bahkan ada tiga aspek yang keseluruhan aitemnya gugur yaitu aspek motivasi, aspek disfungsi, dan aspek konflik eksternal. Adanya aspek yang tidak berfungsi ukur baik pada skala menandakan bahwa konstrak ukur tersebut harus dikembangkan secara bottom up agar sesuai dengan konteks perilaku dimana penelitian tersebut akan diberlakukan. 
Tabel 3. Statistik Deskriptif Profile

\begin{tabular}{lllll}
\hline Situasi & Gender & N & Mean & SD \\
\hline Begining proces & Laki-laki & 199 & 17.74 & 4.66 \\
& Perempuan & 366 & 19.83 & 5.09 \\
\hline \multirow{2}{*}{ During proces } & Laki-laki & 199 & 63.26 & 16.72 \\
& Perempuan & 366 & 66.96 & 18.73 \\
\hline
\end{tabular}

Berdasarkan hasil analisis profile kesulitan sedikit sebesar 17,67 persen dan dengan analisis frekuensi dengan hanya 5,12 persen yang tidak mengalami menggunakan norma hipotetik diketahui kesulitan sama sekali. Hasil selengkapnya bahwa 44,7 persen remaja masih mengalami mengenai kesulitan remaja ketika akan kesulitan dalam pengambilan keputusan, 32,51 persen mengalami tingkat kesulitan memulai mengambil keputusan disajikan pada tabel 4 .

sedang. Remaja yang mangalami tingkat

Tabel 4. Sebelum Pengambilan Keputusan Karir

\begin{tabular}{cccc}
\hline Kategori & Range skor & Frekuensi & \% \\
\hline Sangat Sulit & $25-30$ & 88 & 15,55 \\
Sulit & $20-24$ & 165 & 29,15 \\
Sedang & $16-19$ & 184 & 32,51 \\
Sedikit kesulitan & $11-15$ & 100 & 17,67 \\
Tidak ada Kesulitan & $0-10$ & 29 & 5,12 \\
\hline
\end{tabular}

Selama proses pengambilan penurunan kesulitan pengambilan keputusan diketahui bahwa 24,91 persen keputusan namun potensi tingkat kesulitan remaja mengalami kesulitan pengambilan keputusan karir dan 38,16 persen remaja dalam pengambilan keputusan masih mengalami tingkat kesulitan pengambilan keputusan karir sedang. Remaja yang sedikit mengalami kesulitan pengambilan muncul. Hasil selengkapnya mengenai analisis profile kesulitan pengambilan keputusan karir remaja selama proses pengambilan keputusan disajikan pada tabel keputusan karir sebesar 28,45 persen, 5 . sedangkan remaja yang tidak mengalami kesulitan pengambilan keputusan karir sama sekali sebesar 8,48 persen. Walaupun antara proses awal pengambilan keputusan dan saat pengambilan keputuan mengalami

Tabel 5. Selama Proses Pengambilan Keputusan Karir 


\begin{tabular}{llll}
\hline Kategori & Range skor & Frekuensi & \% \\
\hline Sangat Sulit & $97-115$ & 28 & 4,95 \\
Sulit & $98-96$ & 113 & 19,96 \\
Sedang & $60-77$ & 216 & 38,16 \\
Sedikit kesulitan & $41-59$ & 161 & 28,45 \\
Tidak ada Kesulitan & $0-40$ & 48 & 8,48 \\
\hline
\end{tabular}

Remaja yang mengalami kesulitan pengambilan keputusan karir diawal proses sebesar 44,7 (total kategori sulit dan sangat sulit) persen sedangkan saat proses pengambilan keputusan karir sebesar 24,91 persen (total kategori sulit dan sangat sulit) yang menandakan bahwa remaja akan semakin mudah mendapatkan gambaran tentang proses pengolahan informasi saat proses pengambilan keputusan. Pengambilan keputusan karir merupakan proses kemampuan remaja dalam mengolah informasi dalam rangka menentukan keputusan yang tepat untuk karir mereka (Willner et al., 2015). Proses pertimbangan saat mengalami peristiwa langsung mengambil keputusan ternyata lebih menentukan menurunnya tingkat kesulitan saat mengambil keputusan terkait karir.

Analisis perbedaan pengambilan kesulitan karir berdasarkan perbedaan gender disajikan dalam tabel 6. Ada perbedaan tingkat kesulitan pengambilan keputusan antara remaja laki dan remaja perempuan pada awal proses pengambilan keputusan maupun selama proses pengambilan keputuan. Remaja perempuan mengalami kesulitan pengambilan keputusan karir lebih tinggi dibandingkan remaja laki-laki pada saat mengawali proses pengambilan keputusan maupun saat proses pengambilan keputusan berjalan. Hal tersebut bisa dilahat pada tabel 7 mean pada remaja perempuan ketika mengawali pengambilan keputusan lebih tinggi dibanding remaja laki-laki. Begitu pula selama proses pengambilan keputusan remaja perempuan mengalami tingkat kesulitan lebih tinggi dalam pertimbangan karir daripada remaja laki-laki. 
Tabel 6. Uji Perbedaan antar gender

\begin{tabular}{llllll}
\hline Situasi & Sum of Squares & Df & Mean Square & F & Sig. \\
\hline Begining proces & 588.529 & 2 & 294.265 & 12.031 .000 \\
During proces & 2371.478 & 2 & 1185.739 & 3.639 & .027 \\
\hline
\end{tabular}

\section{Kesimpulan}

Berdasarkan temuan di lapangan dan analisis data maka penelitian ini menyimpulkan bahwa ada tiga aspek yang keseluruhan aitem pengukurannya memiliki daya beda rendah yaitu aspek aspek motivasi, aspek disfungsi informasi, dan aspek konflik eksternal. Kondisi remaja yang mengalami kesulitan pengambilan keputusan karir diawal proses sebesar 44,7 persen sedangkan saat proses pengambilan keputusan karir sebesar 24,91 persen. Ada perbedaan tingkat kesulitan pengambilan keputusan karir antara remaja perempuan dan remaja laki-laki. Remaja perempuan mengalami kesulitan pengambilan keputusan karir lebih tinggi dibandingkan remaja laki-laki.

Berdasarkan temuan diatas maka peneliti mengambil keputusan untuk pengembangan penelitian berikutnya. Penelitian yang direncanakan pada tahap berikutnya yaitu pengembangan konstrak ukur kesulitan pengambilan keputusan karir dengan perbaikan aitem, dan menguji validitas prediktif dengan skala yang diasumsikan paralel yaitu skala efikasi diri pengambilan keputusan karir. Penelitian tentang model intervensi yang sesuai dan mudah diaplikasikan oleh guru Bimbingan dan Konseling Karir di sekolah perlu dikembangkan untuk menangani kesulitan pengambilan keputusan yang semakin sulit pada saat proses pengambilan keputusan.

\section{Daftar Pustaka}

Bernier, A., Soucy, N., \& Larose, S. (2004). Attachment state of mind : implications for adjustment to college. Journal of Adolescent Research, 19(6), 783-806. http://doi.org/10.1177/07435584032 60096

Bright, J. E. H., Pryor, R. G. L., \& Harpham, L. (2005). The role of chance events in career decision making. Journal of Vocational Behavior, 66(3), 561-578. http://doi.org/10.1016/j.jvb.2004.05. 001

Garcia, P. R. J. M., Restubog, S. L. D., Bordia, P., Bordia, S., \& Roxas, R. E. O. (2015). Career optimism: The roles of contextual support and career decision-making self-efficacy. Journal of Vocational Behavior, 88, 10-18. http://doi.org/10.1016/j.jvb.2015.02. 004

Gati, I., Gadassi, R., \& Mashiah-Cohen, R. (2012). Career decision-making profiles vs. styles: Convergent and incremental validity. Journal of Vocational Behavior, 81(1), 2-16. http://doi.org/10.1016/j.jvb.2012.03. 004

Gati, I., Gadassi, R., \& Shemesh, N. (2006). The predictive validity of a computerassisted career decision-making system: A six-year follow-up. Journal of Vocational Behavior, 68(2), 205-219. http://doi.org/10.1016/j.jvb.2005.08. 
002

Gati, I., Krausz, M., \& Osipow, S. H. (1996). A taxonomy of difficulties in career decision making. Journal of Counseling Psychology, 43(4), 510-526. http://doi.org/10.1037/0022-

0167.43.4.510

Gati, I., Landman, S., Davidovitch, S., AsulinPeretz, L., \& Gadassi, R. (2010). From career decision-making styles to career decision-making profiles: A multidimensional approach. Journal of Vocational Behavior, 76(2), 277-291. http://doi.org/10.1016/j.jvb.2009.11. 001

Gati, I., Ryzhik, T., \& Vertsberger, D. (2013). Preparing young veterans for civilian life: The effects of a workshop on career decision-making difficulties and selfefficacy. Journal of Vocational Behavior, 83(3), 373-385. http://doi.org/10.1016/j.jvb.2013.06. 001

Germeijs, V., \& Verschueren, K. (2006). High school students' career decisionmaking process: A longitudinal study of one choice. Journal of Vocational Behavior, 68(2), 189-204. http://doi.org/10.1016/j.jvb.2005.08. 004

Germeijs, V., \& Verschueren, K. (2007). High school students' career decisionmaking process: Consequences for choice implementation in higher education. Journal of Vocational Behavior, 70(2), 223-241. http://doi.org/10.1016/j.jvb.2006.10. 004

Guranda, M. (2014). The Importance of Adult's Personality Traits and Professional Interests in Career Decision Making. Procedia - Social and Behavioral Sciences, 136, 522-526. http://doi.org/10.1016/j.sbspro.2014. 05.368

Leung, S. A., Hou, Z. J., Gati, I., \& Li, X. (2011). Effects of parental expectations and cultural-values orientation on career decision-making difficulties of Chinese
University students. Journal of Vocational Behavior, 78(1), 11-20. http://doi.org/10.1016/j.jvb.2010.08. 004

Li, X., Hou, Z.-J., \& Jia, Y. (2015). The influence of social comparison on career decision-making: Vocational identity as a moderator and regret as a mediator. Journal of Vocational Behavior, 86, 10 19. http://doi.org/10.1016/j.jvb.2014.10. 003

Micucci, J. A. (2009). The adolescent in family therapy: harnesing the power of relationship. New York: The Guilford Press.

Patton, W., \& McMahon, M. (2001). Career Development Programs: Preparation for lifelong career decision making. (A. C. for E. R. Ltd, Ed.). Melbourne.

Vertsberger, D., \& Gati, I. (2015). The effectiveness of sources of support in career decision-making: A two-year follow-up. Journal of Vocational Behavior, 89, 151-161. http://doi.org/10.1016/j.jvb.2015.06. 004

Willner, T., Gati, I., \& Guan, Y. (2015). Career decision-making profiles and career decision-making difficulties: A crosscultural comparison among US, Israeli, and Chinese samples. Journal of Vocational Behavior, 88, 143-153. http://doi.org/10.1016/j.jvb.2015.03. 007

Zunker, V. G. (2006). Career counseling: a holistic approach. (L. Gebo, Ed.). Singapore: Thomson. 